\title{
SISTEM INFORMASI GEOGRAFIS TINGKAT KERUSAKAN RUAS JALAN BERBASIS WEB
}

\author{
Maya Selvia Lauryn ${ }^{1}$, Muhammad Ibrohim ${ }^{2}$ \\ ${ }^{1,2}$ Program Studi Informatika Fakultas Teknologi Informasi Universitas Serang Raya \\ ${ }^{1}$ mysellyn@gmail.com, \\ ${ }^{2}$ muhamad.ibrohim01@gmail.com
}

\begin{abstract}
Abstrak - Jalan merupakan suatu prasarana perhubungan darat dan jalur transportasi yang yang sangat vital. Salah satu fungsi jalan adalah sebagai faktor pendorong dalam proses pengembangan serta pemerataan pembangunan suatu wilayah. Bagi Pemerintahan jalan merupakan sarana transportasi yang berpengaruh dalam menjalankan roda perekonomian dan pemerintahan. Saat ini Dinas Pekerjaan Umum Kabupaten Serang masih kesulitan dalam menyajikan informasi data spasial dalam bentuk peta digital, masih kesulitan dalam melakukan pemeliharaan data kondisi jalan, serta belum dipublikasikannya data kondisi jalan sehingga Masyarakat umum sulit memperoleh informasi tentang kondisi jalan tersebut. Sistem Informasi Geografis merupakan salah satu solusi untuk menyajikan data spasial tersebut. Sistem Informasi Geografis adalah teknologi yang menjadi alat bantu untuk menyimpan, memanipulasi, menganalisis dan menampilkan kembali kondisi alam dengan bantuan data. Sistem informasi berbasis web ini dirancang menggunakan model UML (Unified Modelling Language) dengan bahasa pemograman PHP (Hypertext Preprocessor) serta menggunakan MySQL sebagai databasenya. Aplikasi SIG yang digunakan yaitu ArcView, MapServer dan Pmapper. Hasil penelitian menyimpulkan bahwa Sistem Informasi Geografis Tingkat Kerusakan Jalan Kabupaten Serang ini, diharapkan dapat bermanfaat bagi pemerintah khususnya Dinas Pekerjaan Umum Kabupaten Serang dalam penyajian Informasi kerusakan jalan.
\end{abstract}

Kata Kunci : SIG, Kerusakan Jalan.

\section{PENDAHULUAN}

Jalan merupakan suatu prasarana perhubungan darat dan jalur transportasi yang yang sangat vital. Salah satu fungsi jalan adalah sebagai faktor pendorong dalam proses pengembangan serta pemerataan pembangunan suatu wilayah, selain itu jalan juga sangat berperan penting dalam proses perhubungan. Bagi Pemerintahan jalan merupakan sarana transportasi yang berpengaruh dalam menjalankan roda perekonomian dan pemerintahan. Tersedianya infrastruktur jaringan jalan yang memadai merupakan salah satu modal besar untuk meningkatkan kegiatan masyarakat di suatu daerah, baik untuk kegiatan yang bersifat sosial maupun perekonomian. Selain sebagai transportasi, jalan juga berfungsi sebagai media sosialisasi dan aksesibilitas bagi masyarakat. Jika kondisi jalan baik, maka aktifitas perekonomian dan transportasi juga akan menjadi lancar. Untuk itu dibutuhkan pemantauan dan pengelolaan mengenai kondisi jalan agar jalan yang mengalami kerusakan dapat dengan mudah teridentifikasi untuk selanjutnya akan dilakukan perbaikan.

Kabupaten Serang merupakan salah satu Kabupaten/Kota di Provinsi Banten yang terbagi atas 29
Kecamatan dan 326 Desa/Kelurahan dengan jumlah ruas jalan 119 dan panjang 610,33 Km (Dinas PU kabupaten Serang) Yang mengalami tingkat kerusakan baik hingga kerusakan berat. Dalam hal ini pemerintah perlu melakukan pendataan jalan rusak di sekitar wilayah pemerintahannya agar segera dilakukan perbaikan. Saat ini Dinas Pekerjaan Umum Kabupaten Serang masih kesulitan dalam menyajikan informasi data spasial dalam bentuk peta digital, masih kesulitan dalam melakukan pemeliharaan data kondisi jalan, serta belum dipublikasikannya data kondisi jalan sehingga Masyarakat umum sulit memperoleh informasi tentang kondisi jalan tersebut.

Sistem Informasi Geografis merupakan salah satu solusi untuk menyajikan data spasial tersebut. Sistem Informasi Geografis adalah teknologi yang menjadi alat bantu untuk menyimpan, memanipulasi, menganalisis dan menampilkan kembali kondisi alam dengan bantuan data. Selanjutnya sistem ini diharapkan dapat membantu kinerja Dinas PU dalam pengelolaan data kondisi jalan. 


\section{TINJAUAN PUSTAKA}

Tinjauan Penelitian

Andhiko Edy Eka Sura Sembiring (2015), melakukan penelitian tentang "Analisis Tingkat Kerusakan Jalan Menggunakan Aplikasi Sistem Informasi Geografis Di Kota Surakarta dan Sekitarnya" Peneliti membahas tingkat kerusakan jalan di Kota Surakarta dan sekitarnya dengan menggunakan Sistem Informasi Geografis. Menganalisis perbedaan tingkat kerusakan jalan di Kota Surakarta dan sekitarnya berdasarkan faktor-faktor wilayah. Metode yang digunakan dalam penelitian ini adalah survei dengan cara observasi dan pengharkatan beberapa parameter yang digunakan. Teknik pengambilan sampel adalah purposive sampling. Metode analisis yaitu metode pendekatan kuantitatif berupa pengharkatan terhadap parameter. Hasil akhir yang diperoleh dalam penelitian ini adalah Peta Tingkat Kerusakan Jalan di Kota Surakarta dan Sekitarnya skala 1:80.000 dengan dua tingkat yaitu tingkat kerusakan jalan rendah dan tingkat kerusakan jalan sedang.

Muhammad Hanafi An, yang melakukan penelitian tentang "SIG berbasis WEB untuk Sistem Jaringan Jalan Dalam Wilayah Dinas Pekerjaan Umum Binamarga Provinsi Sumatera Selatan "Peneliti membahas tentang Jalan provinsi sebagai kolektor dalam sistem jaringan primer yang menghubungkan Ibu Kota Kabupaten/Kota atau antar Ibu Kota Kabupaten/Kota dan jalan strategis Provinsi. Saat ini Dinas pekerjaan umum Binamarga masih kesulitan dalam penyajian informasi data spasial, kesulitan dalam pemeliharaan data jalan dan kondisi jalan, serta kesulitan dalam memperoleh informasi mengenai jaringan jalan. Karena itu sistem yang akan dibuat adalah Sistem informasi Geografis (SIG) berbasis Web. Metodologi yang akan digunakan adalah metodologi waterfall yang terdiri dari tahap analisis, desain, pengkodean, pengujian. Teknik pengumpulan data yang dilakukan berdasarkan observasi, wawancara dan studi pustaka. Hasil rancangan sistem informasi geografis diharapkan dapat membantu Dinas Pekerjaan Umum dalam memberikan informasi jaringan jalan berbasis web dan membantu pemeliharaan data jalan dan kondisi jalan provinsi di wilayah Sumatera Selatan

\section{Kabupaten Serang}

Kabupaten Serang merupakan salah satu Kabupaten/Kota yang ada di Propinsi Banten, terletak diujung barat bagian utara pulau jawa dan merupakan pintu gerbang utama yang menghubungkan Pulau Sumatera dengan Pulau Jawa dengan jarak $\pm 70 \mathrm{~km}$ dari kota Jakarta, Ibukota Negara Indonesia. Luas wilayah secara administratif tercatat $1.467,35 \mathrm{Km} 2$ yang terbagi atas 28 (dua puluh delapan) wilayah kecamatan dan 320 desa

Secara Geografis wilayah Kabupaten Serang terletak pada koordinat $5^{\circ} 50^{\prime}$ sampai dengan $6^{\circ} 21^{\prime}$ Lintang Selatan dan $105^{\circ} 0^{\prime}$ sampai dengan $106^{\circ} 22^{\prime}$ ' Bujur Timur.
Jarak terpanjang menurut garis lurus dari utara keselatan adalah sekitar $60 \mathrm{~km}$ dan jarak terpanjang dari Barat ke Timur adalah sekitar $90 \mathrm{~km}$, sedangkan kedudukan secara administratif Sebelah Utara dibatasi dengan Kota Serang dan Laut Jawa, Sebelah Timur dibatasi oleh Kabupaten Tangerang, Sebelah barat dibatasi oleh Kota Cilegon dan Selat Sunda, Sebelah Selatan dibatasi oleh Kabupaten Lebak dan Pandeglang.

\section{Jalan}

Jalan adalah prasarana transportasi darat yang meliputi segala bagian jalan, termasuk bangunan pelengkap dan perlengkapannya yang diperuntukkan bagi lalu lintas, yang berada pada permukaan tanah, di atas permukaan tanah, di bawah permukaan tanah dan/atau air, serta di atas permukaan air, kecuali jalan kereta api, jalan lori, dan jalan kabel (Peraturan Pemerintah Nomor 34 Tahun 2006). Berdasarkan Undang-undang No. 13 Tahun 1980 tentang Jalan, menyebutkan bahwa : Jalan adalah suatu prasarana perhubungan darat dalam bentuk apapun meliputi segala bagian jalan termasuk bangunan pelengkap dan perlengkapannya yang diperuntukkan bagi lalu-lintas.

\section{Klasifikasi Jalan}

Berdasarkan Undang-Undang No. 38 tahun 2004, jalan sesuai dengan peruntukannya terdiri atas jalan umum dan jalan khusus. Jalan umum dikasifikasikan menurut sistem, fungsi, status, dan kelas. Sedangkan jalan khusus bukan diperuntukkan bagi lalu lintas umum dalam rangka distribusi barang dan jasa yang dibutuhkan.

\section{Lalu Lintas dan Angkutan Jalan}

Berdasarkan ruang lalu lintas diatur dalam UndangUndang No. 22 Tahun 2009 tentang Lalu Lintas dan Angkutan Jalan yang diklasifikasikan menjadi empat, meliputi :

a. Jalan kelas I, yaitu jalan arteri dan kolektor yang dapat dilalui kendaraan bermotor dengan ukuran lebar tidak melebihi $2.500 \mathrm{~mm}$, ukuran panjang tidak melebihi $18.000 \mathrm{~mm}$, ukuran paling tinggi $4.200 \mathrm{~mm}$, dan muatan sumbu berat 10 ton.

b. Jalan kelas II, yaitu jalan arteri, kolektor, lokal, dan lingkungan yang dapat dilalui kendaraan bermotor dengan ukuran lebar tidak melebihi $2.500 \mathrm{~mm}$, ukuran panjang tidak melebihi $12.000 \mathrm{~mm}$, ukuran paling tinggi $4.200 \mathrm{~mm}$, dan muatan sumbu terberat 8 ton.

c. Jalan kelas III, yaitu jalan arteri, kolektor, lokal, dan lingkungan yang dapat dilalui kendaraan bermotor dengan ukuran lebar tidak melebihi $2.100 \mathrm{~mm}$, ukuran panjang tidak melebihi $9.000 \mathrm{~mm}$, ukuran paling tinggi $3.500 \mathrm{~mm}$, dan muatan sumbu terberat 8 ton. 
d. Jalan kelas khusus, yaitu jalan arteri yang dapat dilalui kendaraan bermotor dengan ukuran lebar melebihi $2.500 \mathrm{~mm}$, ukuran panjang melebihi 18.000 $\mathrm{mm}$, ukuran paling tinggi $4.200 \mathrm{~mm}$, dan muatan sumbu terberat lebih dari 10 ton.

\section{Sistem}

Secara umum sistem dapat didefinisikan sebagai sekumpulan objek, ide, berikut keterkaitannya di dalam mencapai tujuan. Dengan kata lainn adalah sekumpulan komponen ( sub-sistem fisik dan non-fisik/logika) yang saling berhubungan satu sama lainnya dan bekerja sama untuk mencapai tujuan (Prahasta, 2014 : 78).

\section{Sistem Informasi}

Sistem informasi adalah suatu sistem di dalam suatu organisasi yang mempertemukan kebutuhan pengolahan transaksi harian, mendukung operasi, bersifat majerial dan kegiatan strategi dari suatu organisasi dan menyediakan pihak luar tertentu dengan laporan - laporan yang diperlukan (Riyanto, Dkk, 2009).

\section{Sistem Informasi Geografis (SIG)}

\section{Konsep Dasar SIG}

Era komputerisasi membuka wawasan baru dalam proses pengambilan keputusan berikut penyebaran informasi. Sehubung dengan hal ini, data yang mewakili "dunia nyata" bisa disimpan dan diproses hingga disajikan dalam bentuk sederhana. Sebagaimana terlihat pada gambar 2.1 pemahaman terhadap model

"dunia nyata" semakin baik jika proses manipulasi dan presentasi datanya bisa dipahami dengan baik (Prahasta, 2014).

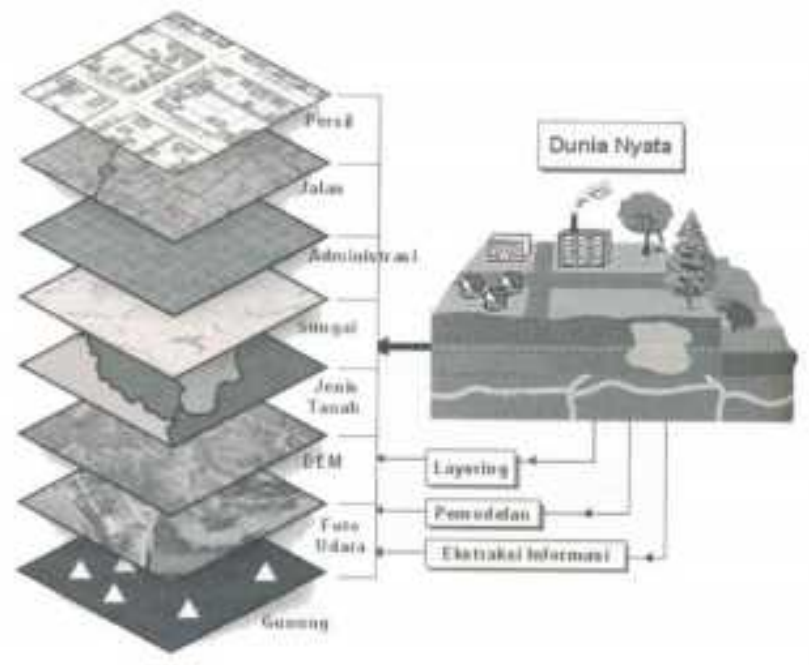

Gambar 2.1 Konsep SIG model dunia nyata (Prahasta, 2014 : 98)

Menurut (Prahasta, 2014), dalam bukunya definisi Sistem Informasi geografis (SIG) bervariasi, hal ini terlihat dari banyaknya definisi SIG yang beredar

\section{Komponen SIG}

Menurut (Prahasta, 2014 : 104) dalam bukunya, SIG merupakan sistem kompleks yang umumnya terintegrasi dengan sistem komputer lainnya ditingkat fungsional dan jaringan. Jika diuraikan SIG terdiri dari komponen dengan berbagai karakteristiknya :

\section{Perangkat keras}

SIG tersedia diberbagai platform perangkat keras mulai dari PC desktop, workstations, hingga multi-user host. Walaupunn demikian, fungsionalitas SIG tidak terikat ketat pada karakteristik fisik perangkat kerasnya hingga keterbatasan memori pada PC dapat diatasi. Adapun perangkat keras yang sering digunakan untuk aplikasi SIG adalah komputer (PC/CPU), mouse, keyboard, monitor (plus VGA-card grafik) yang beresolusi tinggi, digitizer, printer, plotter, receiver GPS, dan scanner.

2. Perangkat lunak

SIG merupakan sistem perangkat lunak dimana sistem basisdatanya memegang peranan kunci. Pada SIG lama, subsistem diimplementasikan oleh modul - modul perangkat lunak hingga tidak mengherankan jika ada perangkat SIG yang terdiri dari ratusan modul program(*.exe) yang dapat dieksekusi sendiri.

3. Data dan informasi geografis

SIG dapat mengumpulkan dan menyimpan data atau informasi yang diperlukan baik tidak langsung (dengan menginport-nya) maupun langsung dengan mendijitasii data spasialnya (on-screen/head-ups pada layar monitor atau cara manual dengan digitizer) dari peta analog dan memasukan data atributnya dari tabel/laporan dengan menggunakan keyboard.

4. Manajemen

Proyek SIG akan berhasil jika dikelola dengan baik dan dikerjakan oleh orang yang memiliki keahlian yang tepat pada semua tingkatan.

\section{ArcView}

ArcView merupakan salah satu perangkat lunak (tool) SIG dan pemetaan yang dikembangkan oleh ESRI (Environmental Systems Research Institute, Inc). ArcView mengorganisasikan perangkat lunaknya kedalam beberapa komponen penting yaitu : Project, Theme, View, Table, Chart, Layout, dan script ( Riyanto, Dkk, 2009)

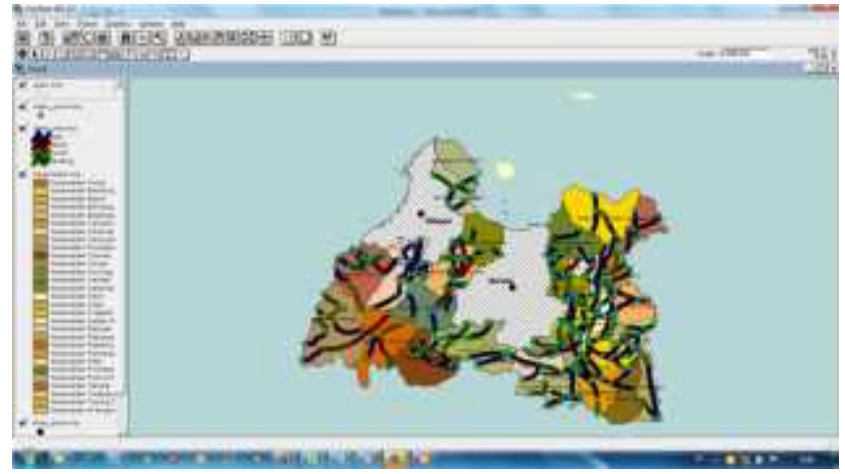


Gambar 2.2 Interface ArcView

\section{Map Server}

Merupakan perangkat lunak free dan open-source yang telah dikembangkan oleh beberapa team dari Universitas Minnesota (UMN) Amerika Serikat. Perangkat ini dapat digunakan untuk mengembangkan aplikasi aplikasi SIG yang berbasis internet. Mapserver selalu memerlukan menimal sebuah mapfile (file teks ASCII berekstensi *.map) yang mendeskripsikan apa dan dimana sumber datanya dan bagaimana data tersebut ditampilkan. (Prahasta, 2007).

\section{ANALISA DAN PERANCANGAN SISTEM}

\section{Teknik pengumpulan data}

Untuk mendapatkan data dalam penyusunan skripsi ini dilakukan beberapa teknik pengumpulan data, antara lain:

\section{Observasi}

yaitu suatu metode untuk memperoleh data langsung dengan cara-cara pengamatan, pengukuran, dan pencatatan terhadap data-data yang diperlukan sesuai dengan tujuan survei. Pengambilan sampel didasarkan pada pertimbangan - pertimbangan, yaitu pada daerah yang dilalui oleh jalur jalan, yang mengalami kerusakan jalan, dan yang memungkinkan mempengaruhi kerusakan jalan.php 2. Wawancara

Yaitu dilakukan dengan berkomunikasi langsung dengan bagian penelitian yang dituju yaitu Dinas Pekerjaan Umum Kabupaten Serang khususnya Bagian Bina Marga 3. Study Pustaka

Melakukan study komprehensif dengan membaca dan mempelajari buku - buku yang menjadi acuan dalam penelitian dan penulisan laporan skripsi ini.

\section{Model Pengembangan Sistem}

Model pengembangan dalam pembuatan Sistem Informasi Geografis (SIG) ini adalah Waterfall.

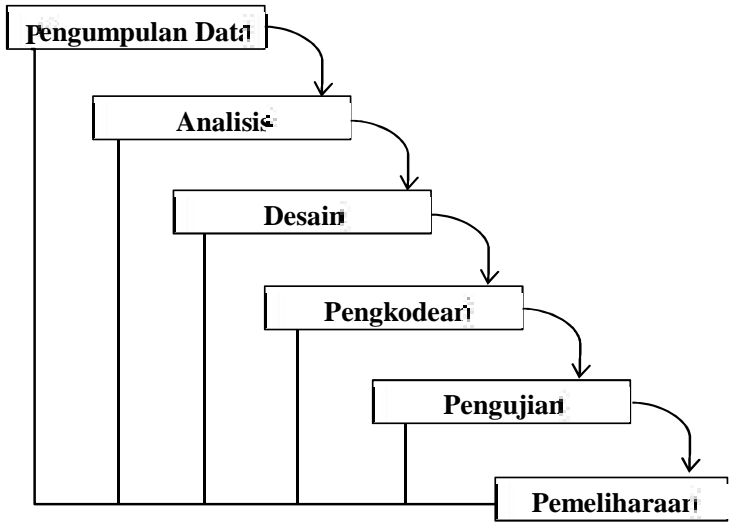

Gambar 3.1 Model Waterfall

Berikut langkah-langkah dari Waterfall Model, yaitu:

1. Pengumpulan data

Pengumpulan data merupakan usaha yang dilakukan untuk memperoleh informasi dalam bentuk data yang dibutuhkan dalam penelitian. Data yang paling dibutuhkan pada pembuatan aplikasi ini adalah data kondisi ruas jalan di Kabupaten Serang. Data dapat diperoleh melalui wawancara, survey atau diskusi. Data tersebut kemudian dianalisis untuk mendapatkan dokumentasi kebutuhan pengguna untuk digunakan pada tahap selanjutnya.

2. Analisis

Tahap berikutnya setelah data terkumpul adalah tahap analisis kebutuhan sistem. Kegiatan ini diintensifkan dan difokuskan pada sistem, yaitu menganalisa kebutuhan dan persyaratan proses pada sistem yang akan dibangun.

3. Desain sistem

Tahap ini dilakukan sebelum melakukan coding. bertujuan untuk memberikan gambaran apa yang seharusnya dikerjakan dan bagaimana tampilannya. Pada proses ini melibatkan struktur data, arsitektur, perangkat lunak, representasi interface dan detail (algoritma) prosedural. Desain yang penulis lakukan adalah berbasis web, agar sistem yang penulis buat dapat diakses dimana saja oleh masyarakat. Serta penambahan Google Maps untuk memperjelas informasi tentang lokasi pada suatu ruas jalan.

4. Pengkodean

Tahapan implementasi merupakan tahapan mengubah rancangan yang telah dibuat menjadi kumpulan kode atau instruksi yang akan dijalankan oleh komputer.Bahasa pemrograman Pemrograman yang digunakan oleh penulis adalah PHP.

5. Pengujian

Penggabungan modul-modul yang sudah dibuat pada tahap sebelumnya dan dilakukan pengujian untuk mengetahui sistem yang dibuat telah sesuai desainnya dan masih terdapat kesalahan atau tidak. Pengujian

6. Operasi dan Pemeliharaan

Pada tahap terakhir perangkat lunak yang sudah dijalankan harus dilakukan pemeliharaan. Pemeliharaan ini termasuk dalam perbaikan kesalahan pada perangkat lunak yang tidak ditemukan pada tahap sebelumnya.

\section{Analisa Data}

Analisa ini bertujuan untuk menentukan data apa saja yang dibutuhkan oleh sistem yang akan dibangun, analisa data dapat dilihat di tabel dibawah ini : 
Tabel 3.1 Analisa Data

\begin{tabular}{|c|l|l|}
\hline No & Nama Data & \multicolumn{1}{|c|}{ Keterangan } \\
\hline 1. & $\begin{array}{l}\text { Data Login } \\
\text { Admin }\end{array}$ & Data yang berisi hak akses sistem. \\
\hline 2. & $\begin{array}{l}\text { Data laporan } \\
\text { kondisi jalan }\end{array}$ & $\begin{array}{l}\text { Data ini berisikan laporan kondisi } \\
\text { jalan Kabupaten Serang. }\end{array}$ \\
\hline 3. & Data Profil & $\begin{array}{l}\text { Data ini berisikan profil Dinas } \\
\text { Pekerjaan Umum Kabupaten } \\
\text { Serang seperti : Motto, Gambaran } \\
\text { Umum dan Struktur Organisasi. }\end{array}$ \\
\hline 4. & Data Kontak & $\begin{array}{l}\text { Data ini berisikan Informasi kontak } \\
\text { Dinas Pekerjaan Umum Kabupaten } \\
\text { Serang seperti : alamat kantor, } \\
\text { no.telp dan social media. }\end{array}$ \\
\hline
\end{tabular}

\section{Analisa Proses}

Analisa proses bertujuan untuk merancang proses apa saja yang akan terjadi pada Sistem Informasi Geografis (SIG) tingkat kerusakan ruas jalan di Kabupaten Serang. adapun daftar prosesnya bisa dilihat pada table dibawah ini :

Tabel 3.2 Analisa Proses

\begin{tabular}{|c|c|c|}
\hline No. & $\begin{array}{l}\text { Nama } \\
\text { Proses }\end{array}$ & Keterangan \\
\hline 1. & $\begin{array}{l}\text { Login } \\
\text { Admin }\end{array}$ & $\begin{array}{l}\text { Proses ini digunakan untuk loginnya } \\
\text { Admin ke sistem, dimana Admin } \\
\text { dapat mengelola data master seperti } \\
\text { menambah, mengubah dan } \\
\text { menghapus data. }\end{array}$ \\
\hline 2. & View Peta & $\begin{array}{l}\text { Proses dimana User yang } \\
\text { berkunjung ke sistem dapat melihat } \\
\text { informasi tingkat kerusakan ruas } \\
\text { jalan Kabupaten Serang yang } \\
\text { ditampilkan pada Peta. }\end{array}$ \\
\hline 3. & $\begin{array}{l}\text { View Menu } \\
\text { Profil }\end{array}$ & 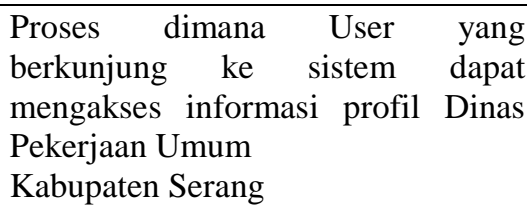 \\
\hline 4 & $\begin{array}{l}\text { Komentar } \\
\text { dan Saran }\end{array}$ & $\begin{array}{l}\text { Proses ini dimana User yang } \\
\text { berkunjung ke sistem dapat } \\
\text { memberikan komentar dan sarannya } \\
\text { dengan menginput nama, email, } \\
\text { komentar dan saran kemudian kirim } \\
\text { Setelah itu Admin dapat melihat } \\
\text { komentar dan saran yang dikirim } \\
\text { oleh User atau pengunjung tersebut. }\end{array}$ \\
\hline
\end{tabular}

\begin{tabular}{|l|l|lrr|}
\hline 5. & Kontak & $\begin{array}{l}\text { Proses ini diamana user } \\
\text { berkunjung ke sistem dapat } \\
\text { mengakses menu kontak yang } \\
\text { berisikan informasi lokasi Dinas } \\
\text { Pekerjaan Umum Kabupaten Serang } \\
\text { antara lain, Alamat kantor, No.Telp, } \\
\text { Email, Facebook dan Twitter. }\end{array}$ \\
\hline 6. & $\begin{array}{l}\text { Tabel } \\
\text { Laporan }\end{array}$ & $\begin{array}{l}\text { Proses ini dimana Admin dapat } \\
\text { menambahkan, mengubah dan } \\
\text { menghapus data kondisi jalan } \\
\text { Kabupaten Serang. }\end{array}$ \\
\hline 7. & LogOut & $\begin{array}{l}\text { Proses ini dimana Admin LogOut } \\
\text { dari menu Admin, dan kembali ke } \\
\text { tampilan Awal. }\end{array}$ \\
\hline
\end{tabular}

\section{Analisa Pengguna}

Dalam analisa pengguna ini bertujuan untuk menentukan siapa saja yang terlibat dalam Sistem Informasi Geografis tingkat kerusakan jalan Kabupaten Serang. Adapun daftar penggunanya bisa dilihat pada table dibawah ini :

Tabel 3.3 Analisa Pengguna

\begin{tabular}{|l|l|l|}
\hline No & $\begin{array}{c}\text { Nama } \\
\text { Pengguna }\end{array}$ & \multicolumn{1}{|c|}{ Hak Akses } \\
\hline 1. & Admin & $\begin{array}{l}\text { Mengelola data master, dimana } \\
\text { Admin dapat menambahkan, } \\
\text { mengedit dan menghapus data. }\end{array}$ \\
\hline 2. & User & $\begin{array}{l}\text { Mengakses halaman utama, profil, } \\
\text { View peta kerusakan jalan dan } \\
\text { kontak Dinas Pekerjaan Umum } \\
\text { Kabupaten Serang }\end{array}$ \\
\hline
\end{tabular}

Analisa Kebutuhan User

Kebutuhan user meliputi apa saja yang dibutuhkan oleh user pada Sistem Informasi Geografis tingkat kerusakan jalan di Kabupaten Serang berbasis web ini berupa :

1. Tampilan peta yang menunjukan tingkat kerusakan ruas jalan.

2. Tampilan profil Dinas Pekerjaan Umum Kabupaten Serang.

3. Tampilan Kontak sebagai informasi lengkap tentang Dinas Pekerjaan Umum Kabupaten Serang seperti alamat kantor, email, facebook dan twitter.

4. Tampilan halaman komentar dan saran, dimana pengunjung dapat memberikan komentar serta saran terhadap Dinas Pekerjaan Umum Kabupaten Serang.

\section{Analisa Kebutuhan Admin}

Kebutuhan Admin meliputi apa saja yang dibutuhkan oleh Admin pada Sistem Informasi Geografis 
tingkat kerusakan jalan di Kabupaten Serang berbasis web ini berupa :

1. Melakukan proses login terhadap sistem.

2. Menambahkan, mengubah dan menghapus data user.

3. Melakukan input data kerusakan ruas jalan di Kabupaten Serang.

4. Mengedit serta menghapus data.

\section{Perancangan Sistem}

Tujuan dari perancangan sistem adalah memberikan gambaran perancangan sistem yang akan dibangun atau dikembangkan untuk memahami alur informasi dan proses dalam sistem. Dalam perancangan sistem informasi geografis tingkat kerusakan ruas jalan di Kabupaten Serang yaitu menggunakan model Unified Modelling Language (UML) yang terdiri dari berbagai simbol dan diagram seperti: Use Case Diagram, Use Case Description, Acivity Diagram, Sequence Diagram, Class Diagrtam dan Collaboration Diagram.

\section{Use Case Diagram}

Use Case digunakan untuk menggambarkan perilaku yang dibutuhkan atau diharapkan dari sistem yang akan dikembangkan. Use Case menyediakan cara untuk mendapatkan pemahaman dari apa yang diharapkan dan dibutuhkan oleh pengguna. Berikut ini adalah Use Case diagram untuk Sistem Informasi Geografis tingkat kerusakan ruas jalan di Kabupaten Serang :

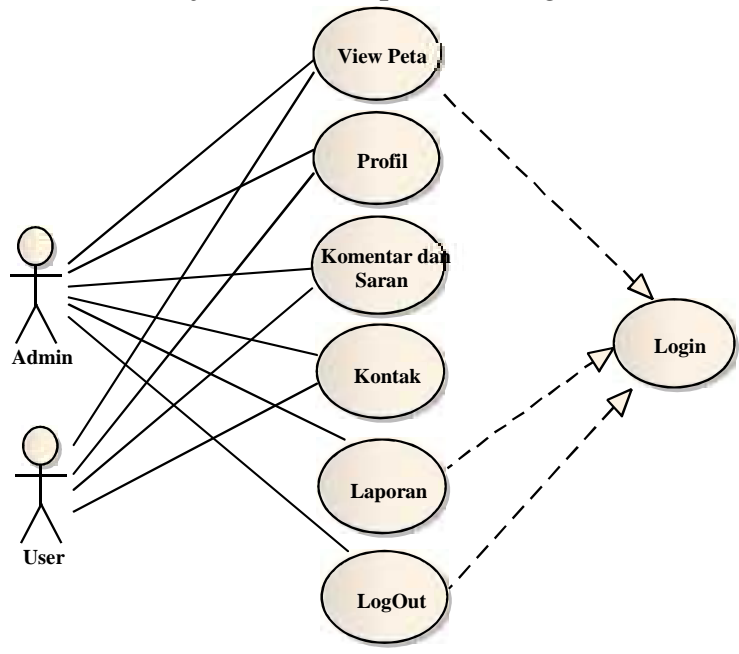

Gambar 3.2 Use Case Diagram

\section{Activity Diagram}

Activity diagram atau diagram aktivitas yaitu salah satu jenis diagram pada UML yang berisi aktivitas dan tindakan yang juga dapat berisi pilihan dan pengulangan. Diagram aktivitas dibuat untuk menjelaskan apa saja yang terjadi pada sistem.

1. Activity Diagram Login
Pada activity diagram login, sistem menjelaskan bagaimana langkah-langkah dalam menampilkan form login. Pada aplikasi Sistem Informasi Geografis tingkat kerusakan ruas jalan ini yang melakukan login hanyalah Admin, sedangkan User tidak. Admin memiliki username dan password untuk login ke sistem.

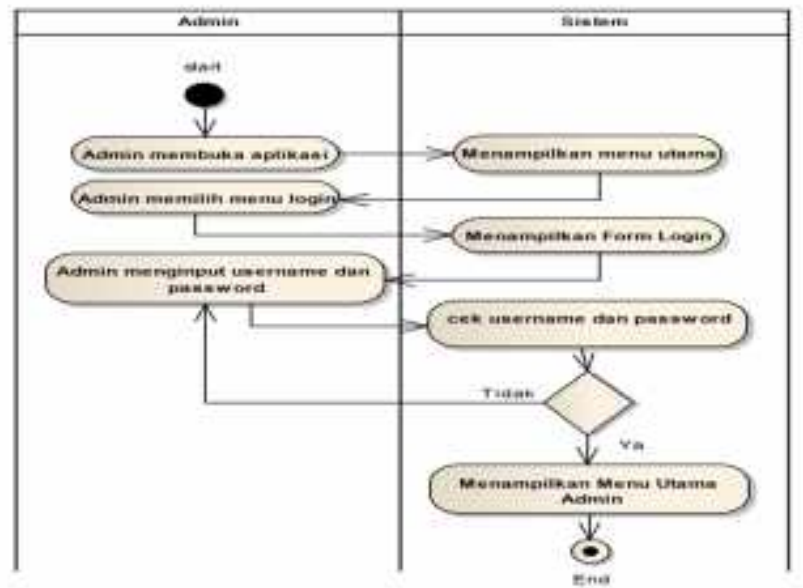

Gambar 3.3 Diagram Activity Login

\section{Activity Diagram View Peta}

Pada aktivity diagram peta, menjelaskan bagaimana Admindan User dapat mengakses atau melihat informasi pada peta. Admin maupun User tidak perlu melakukan login, menu peta tersedia pada menu utama. Menu peta menampilkan informasi tingkat kerusakan ruas jalan Kabupaten Serang

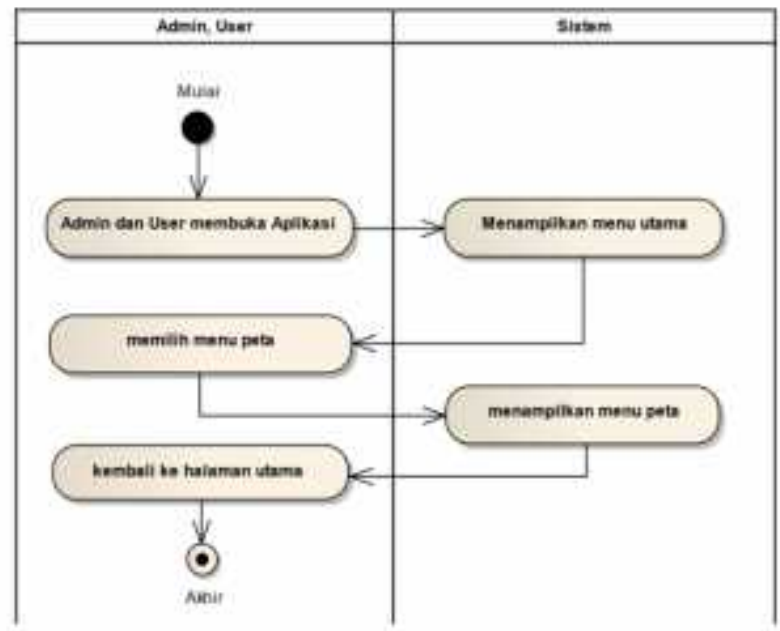




\section{Gambar 3.4 Diagram Activity View Peta}

3. Activity Diagram Profil.

Activity Diagram Profil menjelaskan bagaimana User dapat mengakses menu profil. Dimana pada menu profil terdapat informasi lengkap tentang profil Dinas Pekerjaan Umum Kabupaten Serang. Pada menu profil User dapat melihat informasi seperti visi misi Dinas PU dan struktur organisasi Dinas PU.

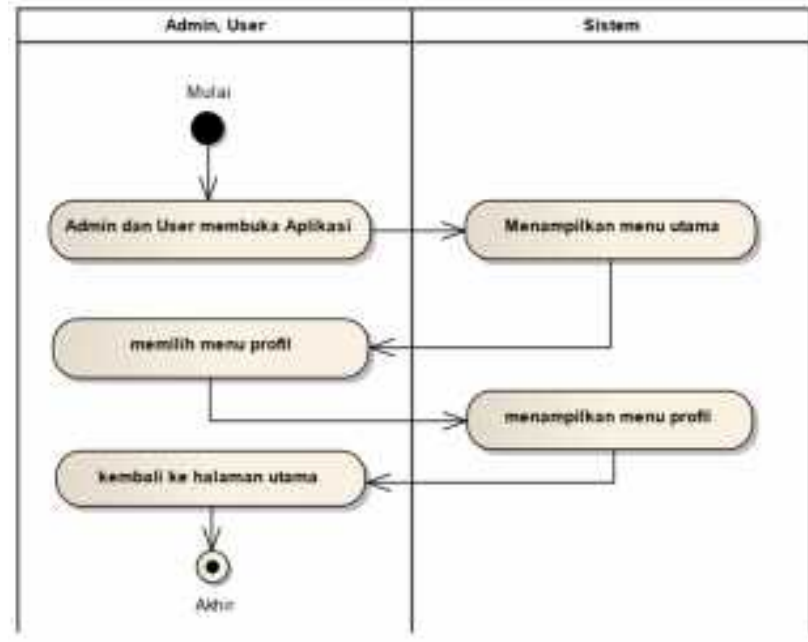

Gambar 3.5 Diagram Activity Profil

4. Activity Diagram Komentar dan saran User.

Digaram ini menggambarkan tentang bagaimana User mengakses menu komentar dan saran. Dimana dengan mengakses menu ini User dapat memberikan komentar dan saran kepada Dinas Pekerjaan Umum Kabupaten Serang.

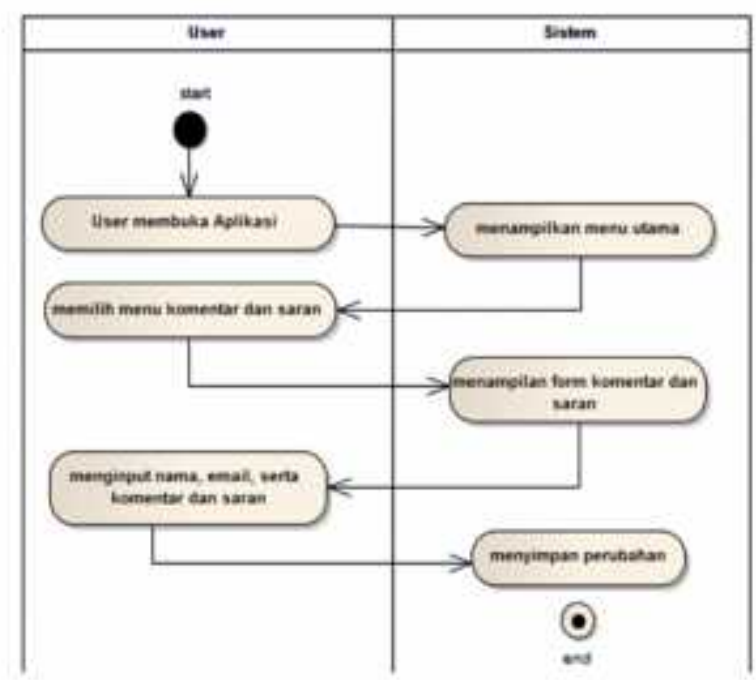

Gambar 3.6 Diagram Activity Komentar dan Saran User

5. Activity Diagram komentar dan saran Admin

Diagram ini menggambar bagaimana Admin mengakses menu komentar dan saran. Admin dapat melihat komentar dan saran yang dikirim oleh User atau pengunjung sistem. Admin dapat menghapus komentar dan saran tersebut

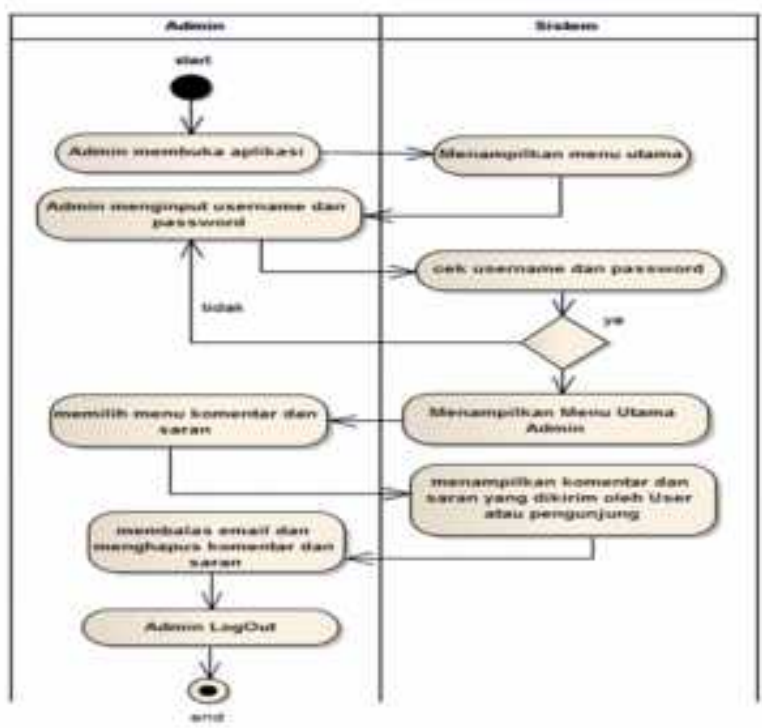

Gambar 3.7 Diagram Activity komentar dan saran Admin

6. Activity Diagram Kontak

Diagram ini menggambarkan dimana User dapat melihat informasi tentang Dinas Pekerjaan Umum Kabupaten Serang dengan membuka menu kontak. Pada menu kontak User atau pengunjung dapat melihat infomasi alamat kantor, telp, email, facebook dan twitter.

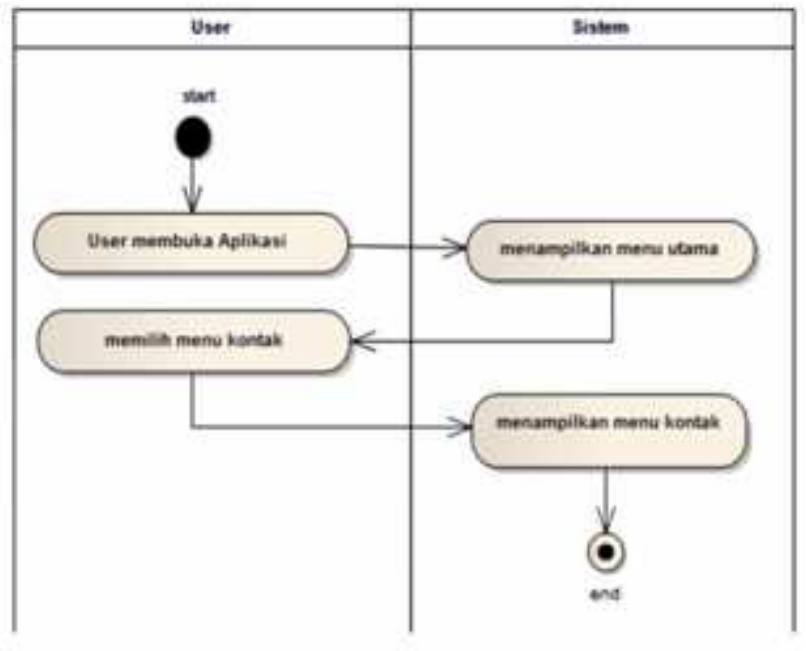


Gambar 3.8 Diagram Activity Kontak

\section{Activity Diagram Laporan}

Diagram ini menggambarkan dimana Admin dapat mengelola tabel laporan kondisi jalan. Admin dapat menambahkan, mengubah dan menghapus data kondisi jalan tersebut. Adapu data yang diinput Admin pada tabel adalah nama ruas jalan, panjang, lebar, kontruksi,kondisi, fungsi jalan, kelas jalan dan keterangan batas jalan. Laporan kondisi jalan hanya dapat diakses oleh Admin.

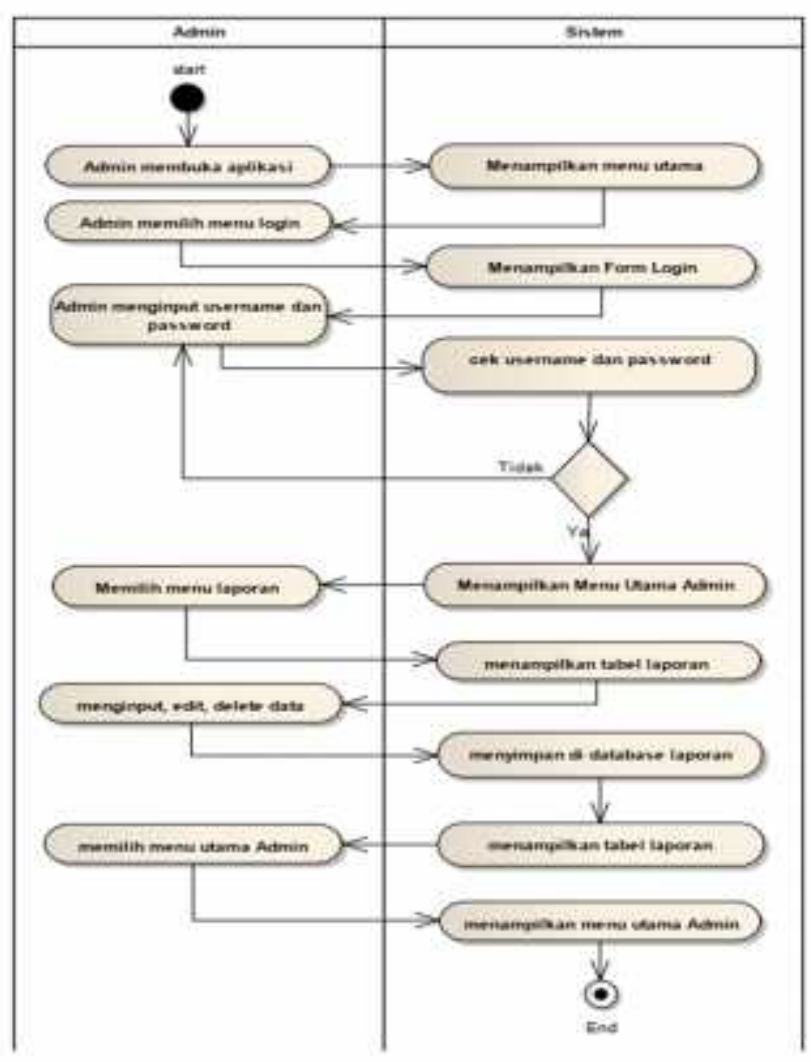

Gambar 3.9 Diagram Activity Laporan

\section{Sequence Diagram}

1. Sequence Diagram Login

Sequensial diagram login menggambarkan bagaimana proses Admin login ke sistem. Dimana Admin menginput username dan password.

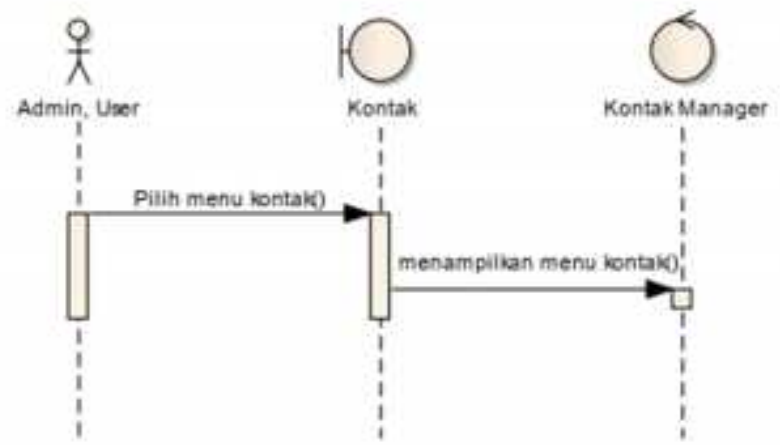

Gambar 3.10 Sequence Diagram Login

2. Sequence Diagram View Peta

Diagram ini menggambarkan bagaimana Admin, User atau Masyarakat yang mengunjungi sistem dapat mengakses atau melihat informasi kerusakan jalan yang ditampilkan pada peta.

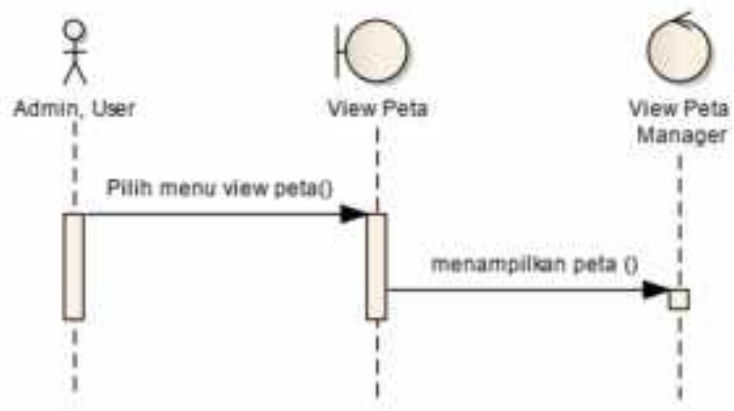

Gambar 3.11 Sequence Diagram View Peta

3. Sequence Diagram Profil

Diagram ini menggambarkan bagaimana User atau

Masyarakat yang mengunjungi sistem dapat mengakses atau melihat informasi profil Dinas Pekerjaan Umum Kabupaten Serang.

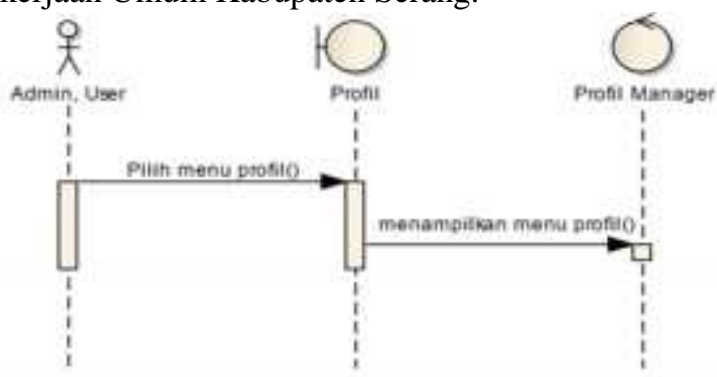

Gambar 3.12 Sequence Diagram Profil

4. Sequence Diagram Profil

Diagram ini menggambarkan bagaimana User atau

Masyarakat yang mengunjungi sistem dapat mengakses atau melihat informasi profil Dinas Pekerjaan Umum Kabupaten Serang.

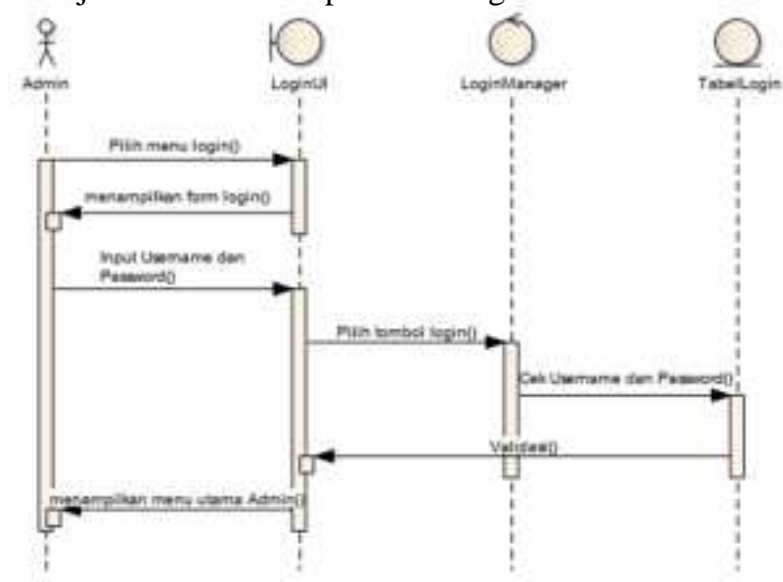


Gambar 3.13 Sequence Diagram Profil

5. Sequence diagram komentar dan saran Admin

Diagram ini menggambarkan bagaimana Admin mengakases menu komentar dan saran. Admin harus melakukan login terlebih dahulu. Komentar dan saran yang dikirim oleh user atau pengunjung dapat dibales oleh Admin melalui Email dan Admin juga dapat menghapus komentar dan saran tersebut

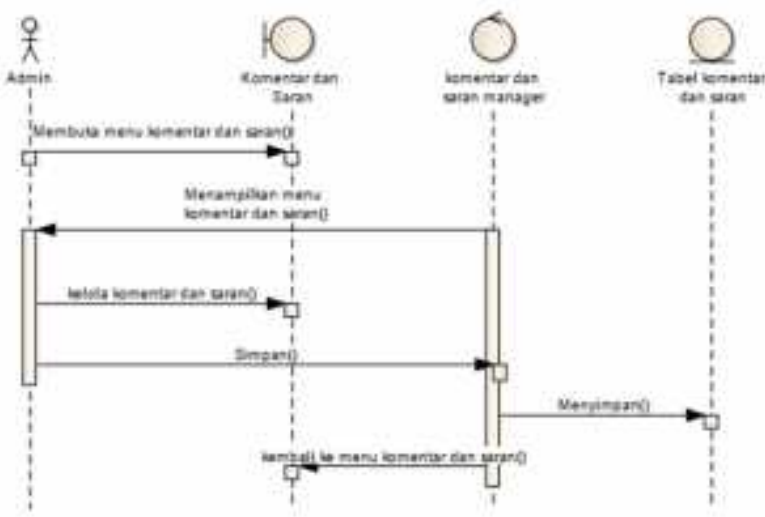

Gambar 3.14 Sequence Diagram komentar dan saran Admin

6. Sequence diagram Kontak

Diagram ini menggambarkan proses Admin mengakses menu kontak. Dimana pada meu kontak terdapat informasi tentang Dinas Pekerjaan Umum Kabupaten Serang

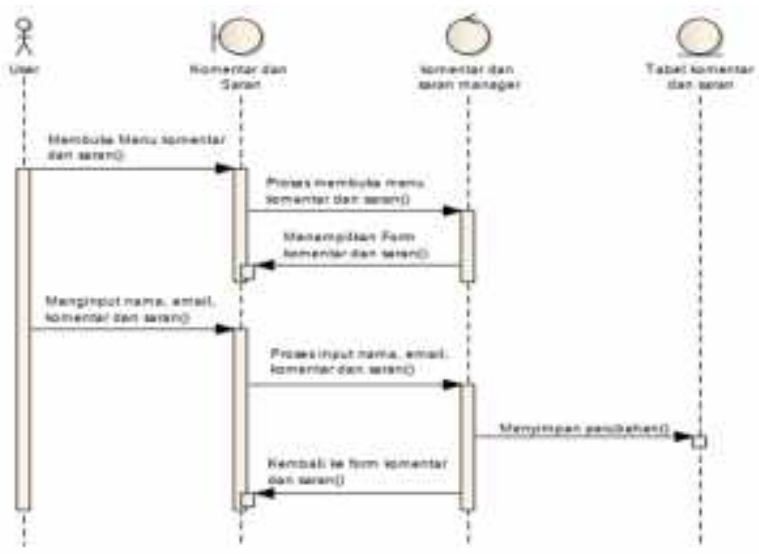

Gambar 3.15 Sequence Diagram Kontak

7. Sequence diagram laporan

Diagram ini menggambarkan proses Admin mengelola table laporan kondisi jalan. Admin dapat menambahkan, mengubah dan menghapus data kondisi jalan tersebut. Adapun data yang diinput Admin pada tabel laporan kerusakan jalan adalah nama ruas jalan,panjang, lebar, kontruksi, kondisi, fungsi jalan, kelas jalan dan keterangan batas jalan. Laporan kondisi jalan hanya dapat diakses oleh Admin.

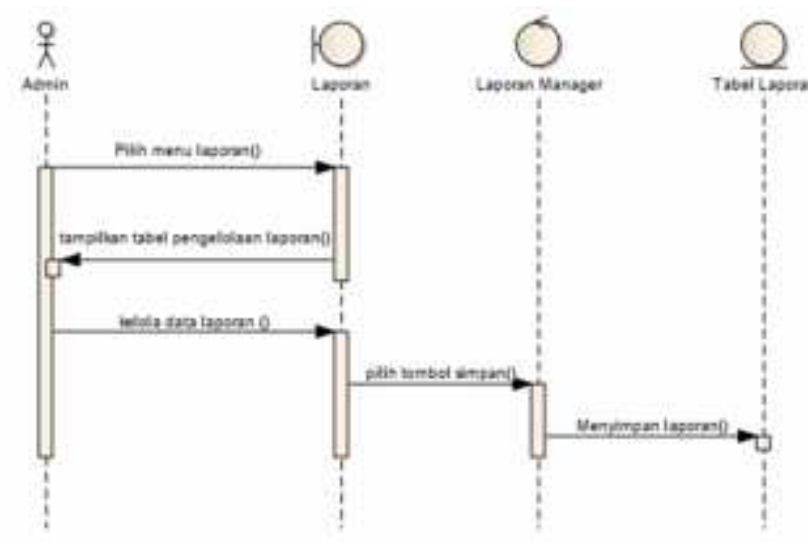

Gambar 3.16 Sequence Diagram Laporan

\section{HASIL DAN PEMBAHASAN}

\section{Tampilan Halaman Menu Utama ( Beranda )}

Halaman menu utama merupakan halaman yang pertama kali di lihat oleh pengunjung sistem. Pada halaman ini terdapat menu utama yang dapat diakses oleh pengunjung. Admin melakukan login terlebih dahulu untuk masuk ke menu Admin, Form Login seperti pada gambar 4.2, sedangkan untuk user atau pengujung sistem tidak perlu melakukan login. Tampilan halaman menu utama aplikasi Sistem Informasi tingkat kerusakan jalan adalah seperti gambar berikut :

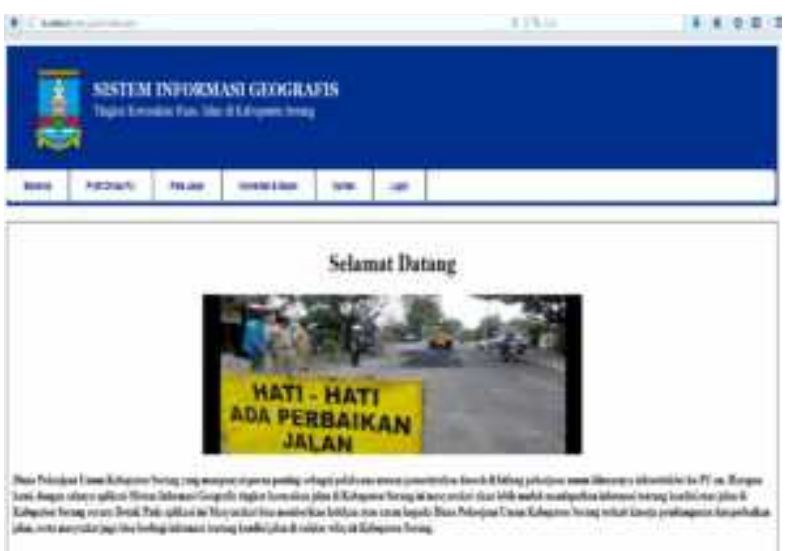

Gambar 4.1 Halaman Menu Utama

\section{Tampilan Form Login}

Menu login digunakan sebagai keamanan sistem dalam penggunaan aplikasi. Admin diharuskan mengisi username dan password untuk masuk ke sistem, jika username dan password salah maka akan tampil jendela 
dialog pemberitahuan bahwa username dan password salah, maka akan kembali ke tampilan form login. Fungsi tombol login adalah untuk validasi username dan password. Selain itu menu login juga untuk dapat mengakses masuk kedalam Aplikasi, sehingga Admin dapat menambahkan, mengedit dan menghapus data.

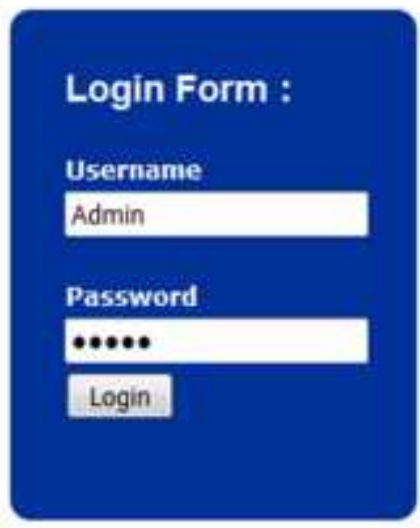

Gambar 4.1 Form Login

\section{Halaman Menu Utama Admin}

Halaman menu utama merupakan halaman yang pertama kali di lihat oleh Admin setelah melakukan login. Menu yang tersedia pada halaman utama Admin yaitu beranda, peta jalan, daftar kerusakan jalan, komentar dan saran, dan logout. Tampilan halaman menu utama Admin aplikasi Sistem Informasi tingkat kerusakan jalan adalah seperti gambar berikut :

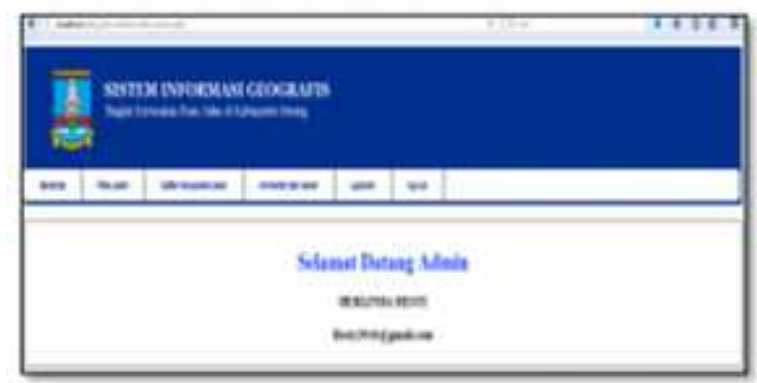

Gambar 4.2 Halaman Menu Utama Admin

\section{Halaman Profil}

Pada menu profil terdapat informasi profil Dinas Pekerjaan Umum Kabupaten Serang seperti motto, gambaran umum dan struktur organisasi dinas PU.

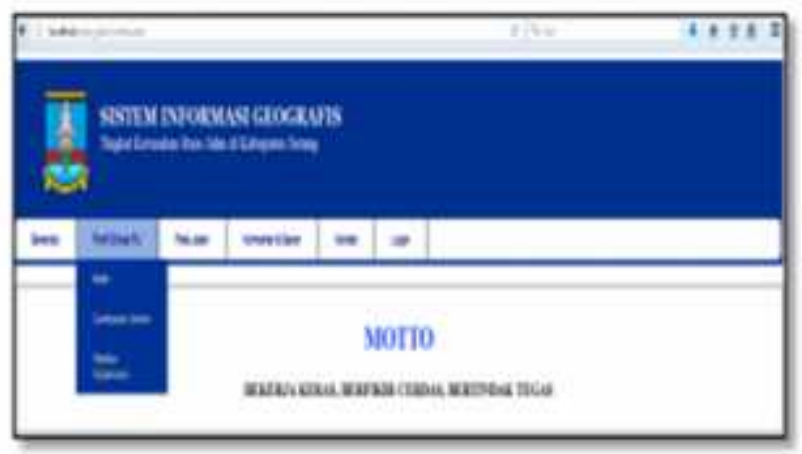

Gambar 4.3 Halaman Profil

\section{Halaman Gambaran Umum}

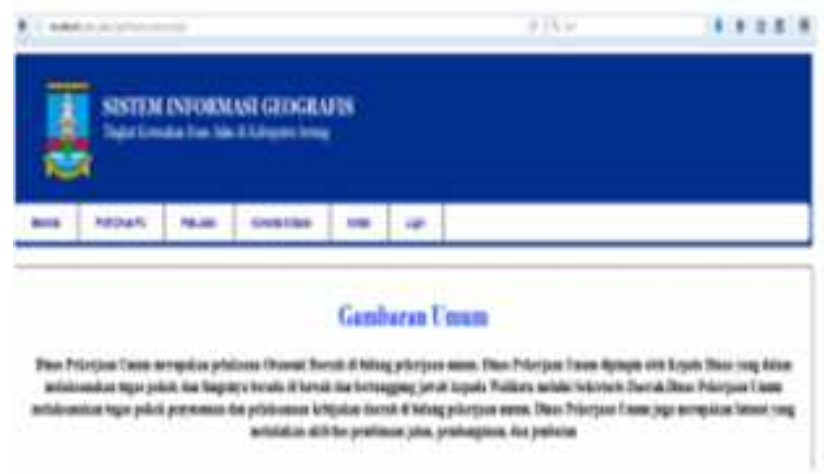

Gambar 4.4 Halaman Gambaran Umum

View Peta

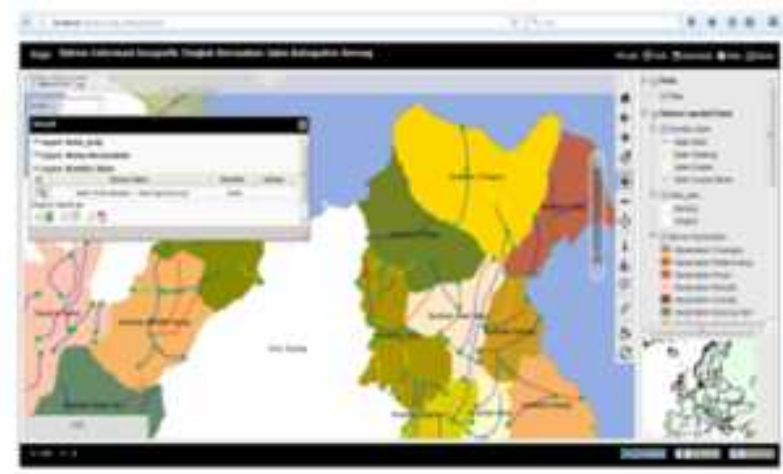

Gambar 4.5 Halaman View Peta

Tampilan Informasi Jalan

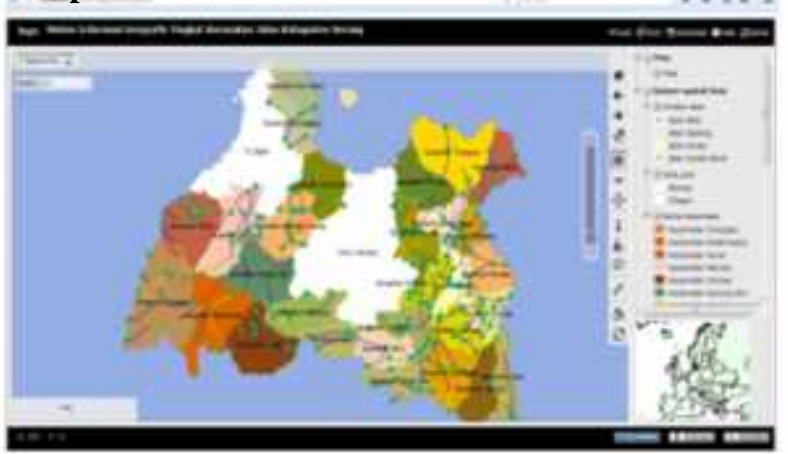


Gambar 4.6 Halaman Informasi Jalan

\section{Tampilan Kecamatan}

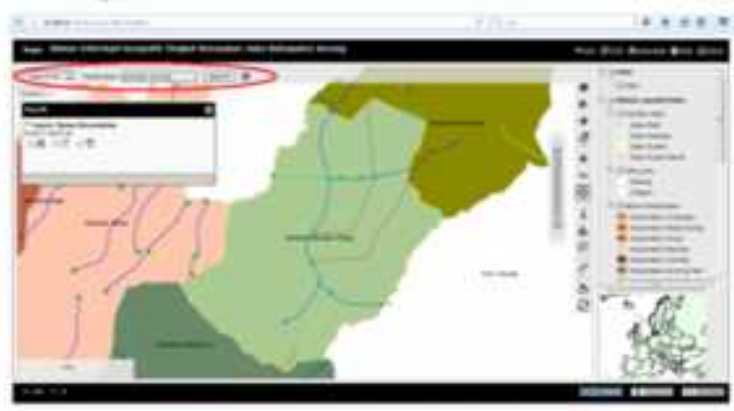

Gambar 4.7 Halaman Tampilan Kecamatan

\section{Tampilan saran dan user Admin}

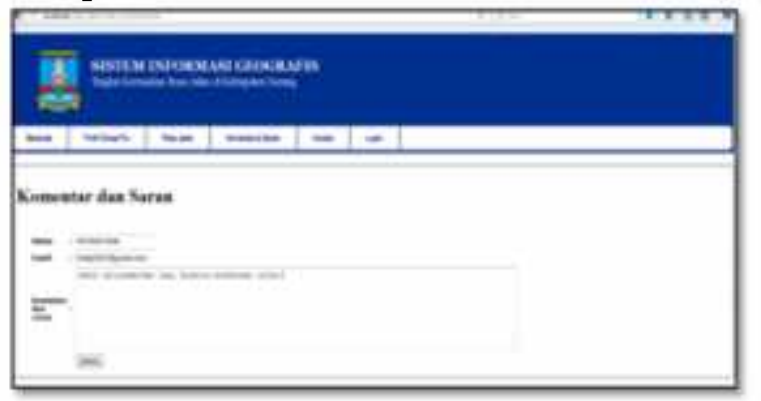

Gambar 4.8 Halaman Tampilan saran dan user admin

\section{Tampil laporan}

Tabel laporan merupakan tabel yang menyimpan data kondisi jalan Kabupaten Serang. Tabel laporan ini hanya dapat diakses oleh Admin

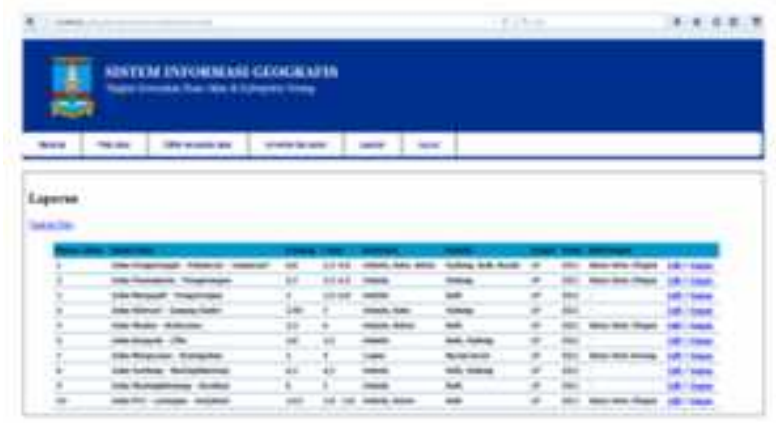

Gambar 4.9 Halaman Tampilan Laporan

\section{Input data kondisi Jalan}

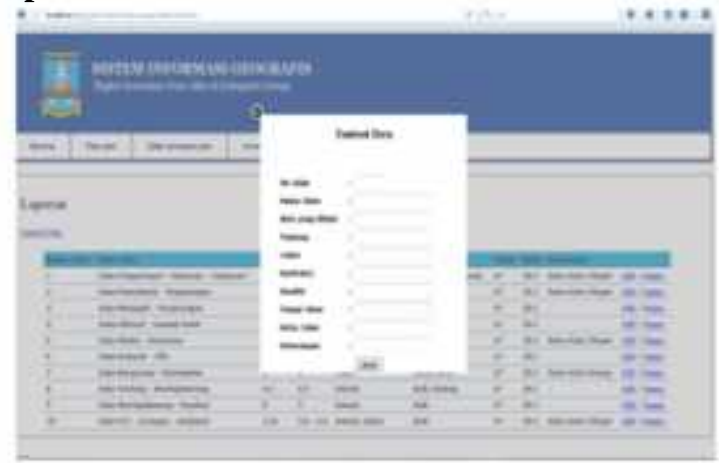

Gambar 4.10 Halaman Tampilan Laporan Halaman Menu Kontak

Menu kontak adalah menu yang menampillkan informasi tentang Kantor Dinas Pekerjaan umum Kabupaten Serang. Informasi yang di tampilkan adalah alamat, telp, email, facebook dan twitter

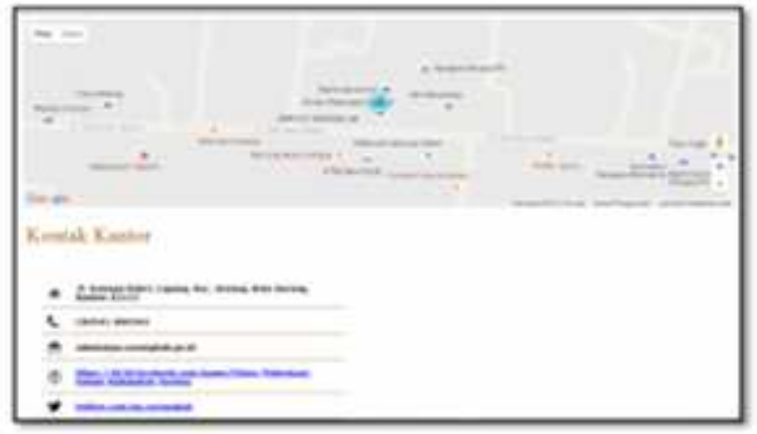

Gambar 4.11 Halaman Menu Kontak

\section{SIMPULAN DAN SARAN}

\subsection{Kesimpulan}

Berdasarkan uraian pada bab-bab sebelumnya, maka dapat ditarik kesimpulan bahwa:

1. Teknologi informasi yang digunakan dalam sistem ini adalah bahasa pemograman PHP, database MySQL, dan Dreamweaver CS5,

2. Pembuatan Sistem Informasi Geografis tingkat kerusakan jalan Kabupaten Serang ini menggunakan aplikasi ArcView, MapServer dan Pmapper.

3. Dalam merancang aplikasi sistem informasi geografis tingkat kerusakan ruas jalan Kabupaten Serang ini, menggunakan model UML (Unified Modelling Language) dengan empat model perancangan yaitu use case diagram, activityd iagram, sequence diagram, collaboration diagram dan class diagram.

4. Dengan adanya aplikasi SIG ini dapat mempermudah kinerja Dinas PU dalam menyajikan Informasi kerusakan jalan kepada Masyarakat mum.

\subsection{Saran}

Berdasarkan kesimpulan diatas, maka memberikan saran. Adapun saran yang penulis kemukakan adalah sebagai berikut:

1. Tidak menutup kemungkinan akan diadakannya pembaharuan secara berkala terhadap aplikasi ini atau melengkapi kelemahan-kelemahan, agar aplikasi ini selalu berjalan optimal dan sejalan dengan perkembangan data dan teknologi. 
2. Sistem Informasi Geografis kerusakan jalan ini berbasis Web, kedepannya dapat dikembangan berbasis Android.

3. Diharapkan sistem ini bermanfaat dan digunakan dengan baik oleh Dinas Pekerjaan Umum Kabupaten Serang, karena program ini memang dibuat untuk membantu kinerja Dinas PU, khususnya bagian bina marga agar lebih efektif.

\section{REFERENSI}

[1] An, Hanafi Muhammad dkk, SIG Berbasis Web Untuk sistem Jaringan Jalan Dalam Wilayah Dinas Pekerjaan Umum Binamarga Provinsi Sumatera Selatan. Kampus STMIK GI MDP Palembang.

[2] Faizi, Syahrie Faizi dan Albarda. 2015. Perancangan GIS Monitor Kondisi Jalan Memanfaatkan Media Sosial Twitter. Jurnal Edukasi dan Penelitian Informatika (JEPIN) Vol. 1, No.2, Sekolah Teknik Elektro dan Informatika, Institut Teknologi Bandung.

[3] Henderi, 2012. Perancangan Sistem Informasi. Serang: Dinas Pendidikan Provinsi Banten.

[4] Kurniawati, Dwi Putri, 2014. Sistem Informasi Geografis Kerusakan Ruas Jalan Di Kota Yogyakarta. Skripsi. Yogyakarta : Jurusan Teknik Informatika, Fakultas Sains Dan Teknologi Universitas Islam Negeri Sunah Kalijaga.

[5] Madcoms. 2011. Dreamweaver CS5 PHP - MySQL Untuk Pemula. Yogyakarta : C.V ANDI OFFSET. Madcoms. 2008. Membuat Desain Web Untuk Pemula. Yogyakarta : C.V ANDI OFFSET.

[6] Prahasta, Eddy, 2014. Sistem Informasi Geografis konsep-konsep dasar (perspektif geodesi dan geomatika). Bandung: Informatika Bandung.

[7] Prahasta, Eddy. 2007. Sistem Informasi Geografis : Membangun Aplikasi WebBased Gis dengan MapsServer. Bandung : Informatika.

[8] Putro Tri Hanggoro, Rochsid, 2011. Perkenalan Dasar tentang CSS.

[9] Riyanto, Prilnali Eka Putra dan Hendi Indelarko. 2009 Pengembangan Aplikasi Sistem Informasi Geografis Berbasis Dekstop dan Web. Yogyakarta : Gaya Media.

[10] S, Rosa A. Dan M. Shalahuddin.2014. Rekayasa Perangkat Lunak Berstruktur dan Berorientasi Objek. Bandung: Informatika Bandung.

[11] Sembiring, Andhiko Edy Eka Sura. 2015. Analisis Tingkat Kerusakan Jalan Menggunakan Aplikasi Sistem Informasi Geografis Di Kota Surakarta Dan Sekitarnya. Publikasi Karya Ilmiah. Surakarta : Fakultas Geografi Universitas Muhamadiyah Surakarta.
[12] Utdirartatmo, Firrar. 2002, Mengelola Database Server MySQL di Linux dan Windows, Yogyakarta : ANDI.

[13] UNSERA, 2015, Pedoman Penulisan Karya Ilmiah. 